Herm Prof. Wiegrete nit sehr Reracichen Gnifen, Mr. L. hiveer

Reprinted from Journal of Medicinal Chemistry, 1993, 36.

Copyright $\odot 1993$ by the American Chemical Society and reprinted by permission of the copyright owner.

\title{
Antipsoriatic Anthrones with Modulated Redox Properties. 1. Novel 10-Substituted 1,8-Dihydroxy-9(10H)-anthracenones as Inhibitors of 5-Lipoxygenase
}

\author{
Klaus Müller," Dieter Gürster, Susanne Piwek, and Wolfgang Wiegrebe \\ Pharmazeutische Chemie I, Universitāt Regensburg, Institut für Pharmazie, D-93040 Regensburg, Germany
}

Received August 13, $1993^{\circ}$

\begin{abstract}
The syntheses, the biological evaluation, and the structure-activity relationships of a novel series of 1,8-dihydroxy-9(10H)-anthracenones bearing acyl-, alkyl-, or alkylidene-linked aromatic substituents in the 10-position are described. The phenylacyl and phenylalkylidene analogs were far more potent inhibitors of 5-lipoxygenase (5-LO) from bovine polymorphonuclear leukocytes $\left(\mathrm{IC}_{50}\right.$ values in the $10^{-7} \mathrm{M}$ range) than the antipsoriatic drug anthralin, whereas phenylalkyl analogs were only weak inhibitors. Among the active compounds were both potent generators of hydroxyl radicals, as determined by deoxyribose degradation, and strong reducers of the stable free radical 2,2-diphenyl-1-picrylhydrazyl (DPPH). However, several derivatives of this series maintained 5-LO inhibitory activity but did not generate hydroxyl radicals and were not reactive with DPPH. In particular, phenylacyl analogs were also 6 times more efficient in inhibition of lipid peroxidation in model membranes than anthralin. Structure-activity relationships have shown that the presence of free phenolic groups in the attached aromatic ring is beneficial but not required for 5-LO inhibitory potency. The inhibitory potency in the 10-phenylacyl series increased with the length of the acyl chain with three methylene units being the optimum, suggesting a specific enzyme interaction which would not be expected for nonspecific redox inhibitors.
\end{abstract}

Psoriasis is a widespread, chronic inflammatory and scaling skin disease, mainly characterized by increased cell proliferation of the epidermis. ${ }^{1}$ There is evidence, however, that hyperproliferation alone is not sufficient to produce a psoriatic lesion, and it has been suggested that the inflammatory component is an important part of the disease process. ${ }^{2}$ The etiology is as yet unknown, but psoriasis is known to be associated with numerous biochemical abnormalities. ${ }^{2}$ A characteristic of lesional skin is the elevated level of oxygenation products of arachidonic acid. In particular, evidence has been provided showing the enhanced production of 5-lipoxygenase (5-LO) products such as leukotriene $\mathrm{B}_{4}\left(\mathrm{LTB}_{4}\right)$ and 5-hydroxyeicosatetraenoic acid (5-HETE) in psoriasis. ${ }^{3-6}$ Moreover, the effects of 5-LO products in the skin correlate with several pathological features of psoriasis, in particular,leukocyte migration and enhanced cell proliferation. ${ }^{7}$ Thus, regulation of 5-LO pathways has become an important target for therapeutic intervention. ${ }^{8-10}$

Probably the most commonly used topical agent for the treatment of psoriasis is anthralin (1,8-dihydroxy-9(10H)anthracenone, dithranol, 1), which is free of mutagenic property and even exhibits some antimutagenic activity. ${ }^{11}$ However, anthralin therapy causes unpleasant side effects. For example, nonaffected skin surrounding a psoriatic lesion to which anthralin is applied is frequently irritated and stained. ${ }^{12}$ Thus, patient compliance is reduced. The mechanism of the irritancy and the mode of action of anthralin are still not fully understood, but substantial evidence suggests that free radicals and active oxygen species are involved. ${ }^{13-19}$ Although these species may be responsible for the skin irritation and the production of staining products, they are presumably central to the clinical efficacy of the drug. Hence it seems difficult to separate main and side effects. Anthralin may act both as an antioxidant and as a prooxidant. ${ }^{20}$ In addition, it was shown to inhibit the 5- and 12-LO pathways of

- Author to whom correspondence should be addressed.

- Abstract published in Advance ACS Abstracts, November 15, 1993. arachidonic acid metabolism in vitro. ${ }^{21,22}$ The biosynthesis of eicosanoids occurs via the formation of free radicals. ${ }^{23}$ Therefore, compounds with antioxidant properties would be expected to be potential inhibitors of 5-LO. ${ }^{24-28}$ Furthermore, oxygen free radicals, which are inflammatory mediators of considerable importance, may be inactivated by such compounds. ${ }^{29,30}$

Although there have been attempts to develop new therapeutically effective derivatives of anthralin, such as triacetoxyanthracene $e^{31} 2$ and butantrone ${ }^{12}$ (3) for which initial reports were promising, later reports have indicated that these compounds were less effective and more irritating than anthralin itself. ${ }^{32,33}$ Accordingly, there is still need for improved antipsoriatic anthrones that are effective at low dose with low irritancy.

The aim of the present study was to modulate the intensity of active oxygen release by 1,8-dihydroxy-9(10H)anthracenones, which may permit a separation of antipsoriatic and inflammatory effects. This modulation can be achieved by partially blocking the $\mathrm{C}-10$ position, which is responsible for the production of the superoxide radical, ${ }^{14}$ a precursor in the formation of the hydroxyl radical by anthralin. ${ }^{15}$

A series of anthralin analogs bearing acyl-, alkyl-, or alkylidene-linked aromatic substituents in the 10-position was synthesized to investigate the effects on hydroxylradical formation and 5-LO inhibition. Structure-activity relationships are discussed with respect to the following redox properties of the compounds which were recently established for anthralin: 19 reactivity against the stable free radical 2,2-diphenyl-1-picrylhydrazyl (DPPH), prooxidant potential as determined by deoxyribose degradation, and inhibitory effect on lipid peroridation in model membranes.

\section{Chemistry}

Introduction of the 10-acyl functionality onto the anthrone nucleus (compounds 4a-u) was achieved by reaction of the appropriate acyl chlorides with anthralin 
Chart I. Anthralin (1), Resonance-Stabilized Deprotonated Forms of Anthralin 1a,

Triacetoryanthracene 2, Butantrone (3), and Lonapalene<smiles>O=C1c2c(O)cccc2Cc2cccc(O)c21</smiles>

1<smiles>CC(C)C</smiles><smiles>O=C1c2c(O)cccc2-c2cccc(O)c21</smiles><smiles>[O-]c1c2cc3cccc(O)c3c1C(O)=CC=C2</smiles>

$1 \mathrm{a}$<smiles>CC(=O)OC1=CC=Cc2cc3cccc(OC(C)=O)c3c1c2OC(C)=O</smiles>
2<smiles>COc1c(OC)c(OC(C)=O)c2cc(Cl)ccc2c1OC(C)=O</smiles>

lonapalene

Scheme I*<smiles>O=C(Cl)[X]c1ccccc1</smiles>
(a)<smiles>[R]c1cccc([X])c1C(=O)C1c2cccc(O)c2C(=O)c2c(O)cccc21</smiles><smiles>[R]P(O)COCc1ccccc1</smiles>

${ }^{\circ} \mathrm{R}$ and $\mathrm{X}$ are defined in Table I. Reagents: (a) anthralin, pyridine, toluene, $80^{\circ} \mathrm{C}, \mathrm{N}_{2}$; (b) $\mathrm{Pd}-\mathrm{C}, \mathrm{H}_{2}$, THF, room temperature, atmospheric pressure.

under weakly basic conditions, where acylation takes place at the $\mathrm{C}-10$ position via the carbanion (Scheme I). ${ }^{34}$ The required acyl chlorides were prepared from the corresponding acids according to literature methods. ${ }^{35,36} \mathrm{Be}-$ cause ether cleavage of $4 \mathrm{c}$ with boron tribromide resulted in loss of the acyl function at C-10, the desired phenolic analogs 4r-u were prepared by hydrogenolytic cleavage of benzyl ethers 4d-f and 41 (Scheme I).

Scheme II illustrates the synthesis of the 10-phenylalkylidene derivatives $7 \mathbf{a}-\mathbf{r}$. To this end, a new method for attaching carbon substituents to the 10-position of anthralin had to be established. Attempts to obtain the desired compounds by condensation of anthralin with various benzaldehydes in the presence of piperidine or other basic additives failed. However, the use of $\alpha$-chloro methyl ethers proved to be successful. Thus, conversion of suitable aldehydes to their dimethyl acetals followed by treatment with acetyl chloride provided the corre-
Scheme II*<smiles>COC(=O)c1ccc(-[R]2ccccc2)cc1</smiles><smiles>COC(Cc1ccccc1)C1c2cccc(O)c2C(=O)c2c(O)cccc21</smiles>

$6 a \cdot 6 m$ (d)<smiles>O=C1c2c(O)cccc2C(=CCc2ccccc2)c2cccc(O)c21</smiles>

71<smiles>O=C1c2c(O)cccc2C(=Cc2ccccc2)c2cccc(O)c21</smiles>

$7 a \cdot 7 h, 7] \cdot 7 m$

$\left.\begin{array}{ll}\text { 7e } & R=\mathrm{CN} \\ 7 n & R=\mathrm{COOH} \\ 70 & R=\mathrm{CO}_{2} \mathrm{CH}_{3} \\ 7-7 h & R=\mathrm{OCH}_{3} \\ 7 p-7 \mathrm{r} & R=\mathrm{OH}\end{array}\right)(\mathrm{h})$

$\stackrel{(e)}{\longrightarrow}$<smiles>O=C1c2c(O)cccc2C(/C=C/c2ccccc2)c2cccc(O)c21</smiles>

8 a $R$ and $n$ are defined in Table I. Reagents: (a) trimethyl orthoformate, $\mathrm{MeOH}$, concentrated $\mathrm{H}_{2} \mathrm{SO}_{4}$, acetyl chloride, thionyl chloride, $50-60^{\circ} \mathrm{C}$; (b) anthralin, $\mathrm{DBU}, \mathrm{CH}_{2} \mathrm{Cl}_{2}, \mathrm{~N}_{2}, 0^{\circ} \mathrm{C}$; (c) pyridine, $\mathrm{N}_{2}, 116^{\circ} \mathrm{C}$; (d) DBU, MeOH, room temperature, $3 \mathrm{~min}$; (e) DBU, $\mathrm{MeOH}$, room temperature, $10 \mathrm{~h}$; (f) $\mathrm{H}_{2} \mathrm{SO}_{4} 50 \%$, glacial acetic acid; (g) $\mathrm{MeOH}$, concentrated $\mathrm{H}_{2} \mathrm{SO}_{4}$; (h) $\mathrm{BBr}_{3}, \mathrm{CH}_{2} \mathrm{Cl}_{2},-70^{\circ} \mathrm{C}, \mathrm{N}_{2}$.

sponding $\alpha$-chloro methyl ethers $5 \mathbf{a}-\mathbf{m}$. In most cases, $\alpha$-chloro methyl ethers were used in crude form because purification led to decomposition. Alkylation of anthralin with $\alpha$-chloro methyl ethers in the presence of the nonnucleophilic base 1,8-diazabicyclo[5.4.0] undec-7-ene (DBU) at $0^{\circ} \mathrm{C}$ gave 1,8-dihydroxy-10-(1-methoxy- $\omega$-phenylalkyl)$9(10 H)$-anthracenones $6 \mathbf{a}-\mathbf{m}$. Base-catalyzed (pyridine) elimination of a molecule of methanol afforded $7 \mathbf{a}-\mathbf{h}$ and $7 j-m$ in good yields. Derivative 70 was obtained by acid hydrolysis of benzonitrile 7e and subsequent esterification of the acid 7n. The 10-(hydroxyphenyl)methylene derivatives $7 p-r$ were obtained by deprotection of the corresponding methyl ethers $7 f-h$ with boron tribromide in methylene chloride. Under identical conditions as described for $7 \mathrm{a}-\mathrm{h}$, conversion of $6 \mathbf{i}(n=1)$ afforded an isomeric mixture of $7 i$ and 8 in a 65:35 ratio. $7 i$ was prepared selectively from $6 i$ by reaction with DBU at room temperature (3 min). Further reaction $(10 \mathrm{~h})$ of $7 \mathrm{i}$ with DBU provided the isomerically pure (>99\%) 8 as confirmed by HPLC analysis. Coupling constants of the olefinic protons $(J=15 \mathrm{~Hz}$ ) indicated the compound was in the $E$ configuration.

The C-10-benzylated anthralin derivatives (9a-c and 10) were prepared as outlined in Scheme III. The synthesis of the monobenzylated compounds $9 a-c$ was accomplished by reaction of anthralin with the corresponding benzyl halides in the presence of potassium carbonate in acetone. 
Table I. Redox Properties of and 5-LO Inhibition in Bovine PMNL by 10-Phenylacyl- and 10-Phenylalkylidene-Substituted 1,8-Dihydroxy-9(10H)-anthracenones

\begin{tabular}{|c|c|c|c|c|c|c|}
\hline compd & $\mathrm{X}$ or $n$ & $\mathbf{R}$ & 5-LO IC $\mathrm{I}_{60}(\mu \mathrm{M})^{a}$ & $k_{\mathrm{DPPH}}\left(\mathrm{M}^{-1} \mathrm{~s}^{-1}\right)^{b}$ & $\begin{array}{c}\text { deoryribose degradation } \\
(\mu \mathrm{mol} \text { of } \mathrm{MDA} / \mathrm{mmol})^{e}\end{array}$ & LPO IC So $_{50}(\mu \mathrm{M})$ \\
\hline 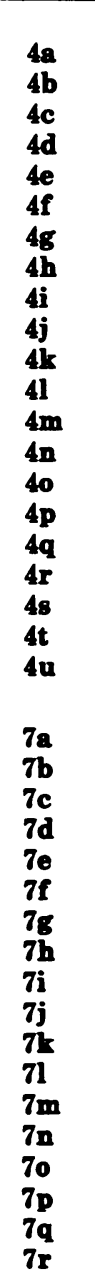 & $\begin{array}{l}\mathrm{X} \\
\mathrm{CH}_{2} \\
\mathrm{CH}_{2} \\
\mathrm{CH}_{2} \\
\mathrm{CH}_{2} \\
\mathrm{CH}_{2} \\
\mathrm{CH}_{2} \\
\mathrm{CH}_{2} \\
\left(\mathrm{CH}_{2}\right)_{2} \\
\left(\mathrm{CH}_{2}\right)_{2} \\
\left(\mathrm{CH}_{2}\right)_{2} \\
\left(\mathrm{CH}_{2}\right)_{2} \\
\left(\mathrm{CH}_{2}\right)_{2} \\
E-\mathrm{CH}_{2}=\mathrm{CH} \\
E-\mathrm{CH}_{2} \mathrm{CH} \\
E-\mathrm{CH}_{2}=\mathrm{CH} \\
\left(\mathrm{CH}_{2}\right)_{3} \\
\left(\mathrm{CH}_{2}\right)_{4} \\
\mathrm{CH}_{2} \\
\mathrm{CH}_{2} \\
\mathrm{CH}_{2} \\
\left(\mathrm{CH}_{2}\right)_{2} \\
n \\
0 \\
0 \\
0 \\
0 \\
0 \\
0 \\
0 \\
0 \\
1 \\
2 \\
2 \\
3 \\
4 \\
0 \\
0 \\
0 \\
0 \\
0 \\
\end{array}$ & 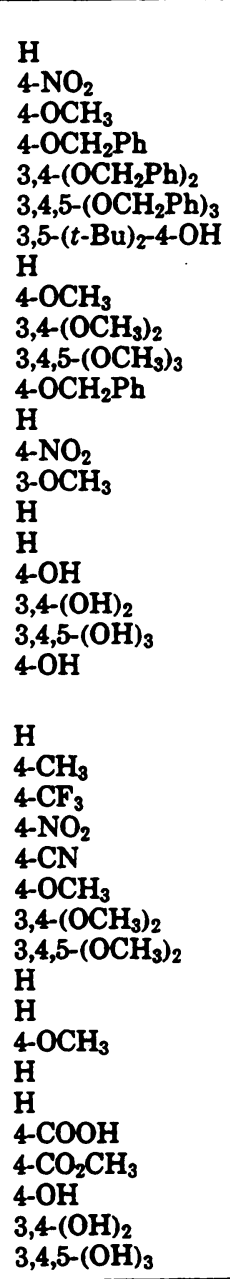 & $\begin{array}{l}11 \\
7 \\
0.5 \\
0.6 \\
(34 \% \text { at } 30) \\
(0 \% \text { at } 30) \\
10 \\
0.5 \\
1 \\
17 \\
14 \\
2 \\
17 \\
6 \\
3 \\
0.3 \\
2 \\
14 \\
11 \\
0.3 \\
1 \\
(34 \% \text { at } 30) \\
(23 \% \text { at } 30) \\
(33 \% \text { at } 30) \\
2 \\
(34 \% \text { at } 30) \\
(<10 \% \text { at } 30) \\
(<10 \% \text { at } 30) \\
(<10 \% \text { at } 30) \\
(35 \% \text { at } 30) \\
6 \\
(24 \% \text { at } 30) \\
(21 \% \text { at } 30) \\
(0 \% \text { at } 30) \\
(<10 \% \text { at } 30) \\
(<10 \% \text { at } 30) \\
4 \\
0.5 \\
0.4\end{array}$ & $\begin{array}{c}16.4 \pm 1.7 \\
63.7 \pm 6.6 \\
15.1 \pm 0.7 \\
13.3 \pm 0.6 \\
15.0 \pm 0.4 \\
15.3 \pm 0.3 \\
\gg 100^{d} \\
10.3 \pm 1.4 \\
7.4 \pm 0.7 \\
8.7 \pm 0.8 \\
10.3 \pm 1.1 \\
8.8 \pm 0.1 \\
>100^{d} \\
\gg 100^{d} \\
>100^{d} \\
10.1 \pm 0.2 \\
10.8 \pm 0.9 \\
14.7 \pm 1.3 \\
\gg 100^{d} \\
\gg 100^{d} \\
7.8 \pm 0.5 \\
c \\
c \\
c \\
c \\
c \\
c \\
c \\
c \\
c \\
c \\
c \\
c \\
c \\
c \\
c \\
>100^{d} \\
\gg 100^{d} \\
\gg 100^{d} \\
\end{array}$ & $\begin{array}{l}<0.2 \\
<0.2 \\
<0.2 \\
<0.2 \\
<0.2 \\
<0.2 \\
<0.2 \\
<0.2 \\
1.40 \pm 0.17^{f} \\
<0.2 \\
<0.2 \\
<0.2 \\
1.66 \pm 0.04^{f} \\
0.88 \pm 0.18^{f} \\
i \\
<0.2 \\
<0.2 \\
0.36 \pm 0.07^{f} \\
6.26 \pm 0.28^{f} \\
2.99 \pm 0.23^{f} \\
2.59 \pm 0.21^{f} \\
\\
<0.15 \\
<0.15 \\
<0.15 \\
<0.15 \\
<0.15 \\
<0.15 \\
<0.15 \\
<0.15 \\
<0.15 \\
<0.15 \\
<0.15 \\
<0.15 \\
<0.15 \\
<0.15 \\
<0.15 \\
<0.15 \\
0.44 \pm 0.01^{f} \\
6.03 \pm 0.08^{f}\end{array}$ & $\begin{array}{c}2^{h} \\
2^{h} \\
i \\
i \\
i \\
i \\
2^{h} \\
2^{h} \\
i \\
i \\
i \\
i \\
i \\
i \\
i \\
i \\
i \\
2^{h} \\
1 \\
2^{h} \\
i \\
\\
8^{h} \\
i \\
i \\
14 \\
i \\
i \\
i \\
i \\
4^{h} \\
2^{h} \\
i \\
i \\
i \\
i \\
8^{h} \\
2^{h} \\
2^{h}\end{array}$ \\
\hline
\end{tabular}

a Inhibition of 5-HETE and LTB 4 biosynthesis in bovine PMNL. Inhibition was significantly different with respect to that of the control, $n=3$ or more, $P<0.01$. Values in parentheses are percent inhibition at the indicated concentrations $(\mu \mathrm{M})$, and standard errors average $10 \%$ of the indicated values. ${ }^{b}$ Reducing activity against 2,2-diphenyl-1-picrylhydrazyl with an equimolar amount of the test compound. ${ }^{c}$ Not reactive; $k_{\mathrm{DPPH}}<1 \mathrm{M}^{-1} \mathrm{~s}^{-1}$. d Highly reactive (approximate values). e Deoxyribose-damaging property as a measure of hydroxyl-radical formation. Indicated values are $\mu \mathrm{mol}$ of malondialdehyde/mmol of deoryribose released by $75 \mu \mathrm{M}$ test compound (controls $<0.1$ ). $f$ Values are significantly different with respect to the control, $P<0.01$. I Inhibition of lipid peroxidation in bovine brain phospholipid liposomes; $n=3$ or more. ${ }^{n}$ Values are significantly different with respect to anthralin, $P<0.01$. $^{i}$ Not determined.

The dibenzylated 10 was obtained in an analogous manner using the requisite molar ratio of benzyl chloride.

\section{Biological Evaluation}

Inhibition of 5-Lipoxygenase. The anthrone derivatives were evaluated for their ability to inhibit the production of $\mathrm{LTB}_{4}$ and 5-HETE in isolated bovine polymorphonuclear leukocytes (PMNL). 37,38 Leukotriene biosynthesis was initiated with Caionophore A23187. $^{2}$ TB $_{4}$ and 5-HETE concentrations were measured by reversedphase HPLC with UV detection. Table I summarizes the inhibitory potencies of the new compounds as expressed by their IC $_{50}$ values. Several compounds in our series had IC $_{50}$ values ranging between 0.3 and $0.6 \mu \mathrm{M}$ and were far more potent than anthralin ( $37 \mu \mathrm{M}$ in this test). Data for known antipsoriatic anthrones, the standard 5-LO inhibitor nordihydroguaiaretic acid (NDGA) and lonapalene, ${ }^{9}$ a 5-LO inhibitor that showed clinical efficacy as an antipsoriatic agent, are given in Table II. The effect of anthralin itself on arachidonic acid lipoxygenation was previously reported. In human neutrophils and bovine neutrophils, it inhibits the production of $\mathrm{LTB}_{4}$ with $\mathrm{IC}_{50}$ 
Table II. Redox Properties of and 5-LO Inhibition in Bovine PMNL by Anthralin Derivatives and Standard Drugs

\begin{tabular}{lcccc}
\hline & $5-\mathrm{LO} \mathrm{IC}_{50}(\mu \mathrm{M})^{a}$ & $k_{\mathrm{DPPH}}\left(\mathrm{M}^{-1} \mathrm{~s}^{-1}\right)^{b}$ & deoxyribose degradation $(\mu \mathrm{mol} \text { of MDA/mmol })^{e}$ & $\left.\mathrm{LPO}^{\mathrm{IC}} \mathrm{C}_{50}(\mu \mathrm{M})\right)^{s}$ \\
\hline NDGA & 0.4 & $\gg 100^{d}$ & $0.23 \pm 0.01^{f}$ & $1^{h}$ \\
lonapalene & 0.5 & $c$ & $<0.15$ & $>50$ \\
anthralin & 37 & $24.2 \pm 4.2$ & $2.89 \pm 0.14^{f}$ & 12 \\
butantrone & 33 & $7.0 \pm 0.6$ & $<.24 \pm 0.03^{f}$ & $4^{h}$ \\
triacetoxyanthracene & $(15 \%$ at 30) & $c$ & $<0.15$ & $i$ \\
\hline
\end{tabular}

a-i See footnotes of Table I.

Scheme III*

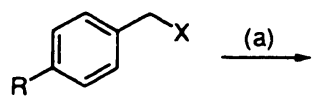

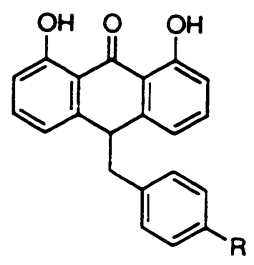

$9 a-9 c$

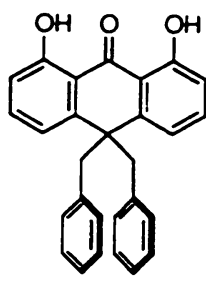

10
${ }^{a} \mathrm{X}=\mathrm{Cl}$ or $\mathrm{Br} . \mathrm{R}=\mathrm{H}, \mathrm{NO}_{2}$, or $\mathrm{OCH}_{3}$. Reagents: (a) $\mathrm{K}_{2} \mathrm{CO}_{3}, \mathrm{KI}$, acetone.

values of 7-74 $\mu \mathrm{M}$ (depending on cell density) and $37 \mu \mathrm{M}$, respectively. 22,39 NDGA and lonapalene gave $\mathrm{IC}_{50}$ values of 0.4 and $0.5 \mu \mathrm{M}$, respectively, in this test. 1,8,9Triacetoxyanthracene and butantrone, which had been in clinical trials for the treatment of psoriasis, are only moderate inhibitors.

Structure-activity studies showed that in general the 10-phenylacyl-substituted analogs 4a-u were more effective than the $\mathrm{C}-10$ phenylalkylidene derivatives $7 \mathrm{a}-\mathrm{r}$. The 10-phenylalkyl- or 10,10-bis(phenylalkyl)-substituted compounds $6 \mathrm{a}-\mathrm{m}, 8,9 \mathrm{a}-\mathrm{c}$, and 10 were without appreciable effect (data not shown).

The 10-phenylacyl-substituted derivatives showed consistently high activity. Introduction of ether groups in the 4-position of the aromatic ring (4c and $4 \mathrm{~d}$ ) strongly increased activity as compared to $4 \mathrm{a}$, although the di- and tribenzylated compounds $4 e$ and $4 f$ were notably less active or inactive, respectively, probably on account of high lipophilicity and limited solubility in the test system. The presence of free phenolic groups did not necessarily lead to improved efficacy in inhibiting 5-LO as compared to nonphenolic compounds. Only if the terminal aromatic ring was substituted by three phenolic groups (4t) was inhibitory action significantly improved as compared to that of the unsubstituted derivative 4a. Furthermore, the inhibitory effects increased with the length of the acyl chain linking the anthrone nucleus and the phenyl ring terminus. Compounds $4 \mathbf{a}, 4 \mathbf{h}, \mathbf{4 p}$, and $4 \mathrm{q}$ demonstrate the beneficial effect of inserting methylene groups between the C-10 carbonyl group and the phenyl rest. Optimal activity was observed when the length of the chain was three carbons (4p). A derivative with a trans double bond in the linking chain (4m) was markedly less active than the corresponding saturated chain compound (4h). Comparison of the $\mathrm{IC}_{50}$ value obtained for butantrone (3) with those obtained for the $\omega$-phenyl derivatives $4 \mathrm{~h}$ and $4 \mathrm{p}$, where the 10-butyryl substituent is replaced by a phenylpropionyl or phenylbutyryl group, respectively, clearly demonstrates that a terminal aromatic ring is required. The mere presence of an acyl substituent at C-10 of anthralin does not necessarily lead to enhanced 5-LO inhibitory activity.

In the 10-phenylalkylidene series, with the exception of the 4-nitro derivative $7 \mathbf{d}$ and the compound $7 \mathbf{j}$, compounds which lack free hydroxy groups in the attached phenyl ring were only moderate inhibitors, whereas the phenolic analogs $7 \mathbf{p}-\mathbf{r}$ strongly inhibited $\mathrm{LTB}_{4}$ formation. The effect of chain length on activity was less pronounced in the phenylalkylidene series; however, the phenylpropylidene chain was optimal for compounds terminated with an unsubstituted phenyl rest $(\mathbf{7 j})$.

Finally, substitution of one or both protons at C-10 of anthralin by benzyl groups (9a-c and 10) abolished 5-LO inhibition, in accordance with the findings that 10-monoand dialkylation of anthralin results in loss of antipsoriatic activity. ${ }^{40,41}$

To rule out apparent inhibition due to nonspecific toxic effects of the potent derivatives, the treated PMNL were checked for viability using the trypan blue exclusion test. Cell viability was always greater than $80 \%$.

Since the use of intact cells requires penetration of the test compound into the cell, control experiments were performed using an homogenate of bovine PMNL which was obtained by sonification of the cell suspension. ${ }^{42}$ The two highly effective compounds $4 p$ and $4 t$ and the less effective compounds $4 \mathbf{f}$ and $7 \mathbf{b}$ were tested at both 3 and $30 \mu \mathrm{M}$. However, $\mathrm{LTB}_{4}$ synthesis was inhibited with comparable potency whether it was determined in whole cells or under cell-free conditions. Thus, there is no barrier to penetration of the compounds. In addition, this demonstrates that the compounds act directly on 5-LO. Effects on other targets, e.g., 5-LO-activating protein, ${ }^{43}$ can be excluded.

Lipophilicity. In some studies on 5-LO inhibitors, relationships between the log of the octanol/water partition coefficients $(\log P)$ and the structural changes resulting in increased activity were reported. ${ }^{25,26,44}$ Thus, as a measure of lipophilicity, we determined the $\log P$ values of the new compounds by a standard HPLC procedure. ${ }^{45}$ In our case, there was no clear relationship found between 5-LO inhibition and lipophilicity. The compounds exhibited a wide range of $\log P$ values (2.61-5.67, Table III). In general, changes in lipophilicity were well tolerated. Compound 4t as the most hydrophilic representative as well as the lipophilic 4d exhibited high activity. The most lipophilic representative with acceptable activity was $\mathbf{7 j}$, although solubility limited the assay concentrations of compounds with greater lipophilicity.

Antioxidant Determination. Because conversion of arachidonic acid into $\mathrm{LTB}_{4}$ by $5-\mathrm{LO}$ is a radical-based oxidation, it is not surprising that most 5-LO inhibitors possess redox properties and can be considered as antioxidants/free-radical scavengers. ${ }^{23}$ These compounds inhibit 5-LO by donating an electron during enzyme catalysis. Because a radical-scavenging antioxidant reacts rapidly with the stable free radical DPPH, ${ }^{46,47}$ we determined the reactivities of the new compounds with DPPH by the decrease in absorbance at $516 \mathrm{~nm}$ (Table I). Phenylacyl substitution at C- 10 of anthralin substantially reduced reactivity with DPPH as compared to that of anthralin (Table II), whereas substitution of both C-10 
hydrogen atoms of anthralin by phenylalkylidene groups nearly abolished reactivity with DPPH. On the other hand, substitution on the phenyl moiety of the side chain by two or three hydroxy groups $(4 \mathbf{s}, 4 t, 7 q$, and $7 \mathbf{r}$ ) dramatically increased redox activity, reflecting the reducing capability of the phenolic hydroxyl. Similar reducing effects were observed for the cinnamoyl derivatives $4 \mathrm{~m}-0$ and the 2,6-di-tert-butylphenol derivative $4 \mathrm{~g}$. The reactivity of compound $7 \mathrm{p}$ which has only one phenolic group is explained by increased resonance stabilization of the corresponding radical.

Hydroxyl-Radical Production. Further studies on the redox behavior of the new compounds have been performed using the deoxyribose assay, which is a sensitive test for the production of hydroxyl radicals. ${ }^{48}$ The release of thiobarbituric-acid-reactive material (expressed as malondialdehyde, MDA) is a measure for hydroxyl-radical formation and thus reflects prooxidant properties of the compounds. ${ }^{49,50}$ The data obtained from this test (Table I) demonstrate that with the exception of the C-10 cinnamoyl anthralin derivatives $(4 \mathrm{~m}-0)$ and the compounds with free phenolic groups in the C-10 substituent $(4 s-u, 7 q$, and $7 r)$, the formation of hydroxyl radicals was substantially reduced with respect to anthralin (Table II). The phenylalkyl substituted compounds $8,9 a-c$, and 10 did not produce hydroxyl radicals (data not shown). The catechol $4 \mathrm{~s}$ and the pyrogallol derivative $7 \mathbf{r}$ led to the release of even larger amounts of MDA than did anthralin (Table II), indicating enhanced formation of hydroxyl radicals. Furthermore, there is no direct relationship between 5-LO inhibitory potency and formation of hydroxyl radicals by 1,8 -dihydroxy- $9(10 H)$-anthracenones.

Inhibition of Lipid Peroxidation. The inhibitory effect on lipid peroxidation of some representative compounds was evaluated with bovine brain phospholipid liposomes which provide an ideal model system for lipid peroxidation studies. ${ }^{51}$ Lipid peroxidation was stimulated with $\mathrm{Fe}^{3+}$ /ascorbic acid. 52 The 10-phenylacylated compounds tested gave $\mathrm{IC}_{50}$ values of 1-2 $\mu \mathrm{M}$ (Table I), being significantly more efficient than anthralin $(12 \mu \mathrm{M}) .{ }^{19}$ Thus, variation of the phenylacyl substituent while leading to significant changes in 5-LO inhibitory activity can maintain high activity in inhibition of lipid peroxidation. Surprisingly, even compounds that were not reactive with DPPH and did not generate hydroxyl radicals did show activity in this test (e.g., $4 a$ and $7 \mathbf{j}$ ). For comparison, the compounds $6 a$ and 10 were without appreciable effect $\left(\mathrm{IC}_{50}\right.$ $>50$, data not shown).

\section{Discussion}

Our results show that the 1,8-dihydroxy-9(10H)-anthracenone nucleus, although not a potent inhibitor of 5-LO in itself, can provide a useful template for the design of potent inhibitors of leukotriene biosynthesis. Moreover, the results support our hypothesis that structural modification of anthralin may lead to control of the release of active oxygen species, as determined by the potency of the compounds to generate hydroxyl radicals. Although 5-LO inhibitory action of 1,8-dihydroxy-9(10H)-anthracenones was not proportionally related to the generation of hydroxyl radicals, compounds which were potent generators of hydroxyl radicals were also effective in 5-LO inhibition (4i, 4s-u, and 7r). Furthermore, those compounds that were substituted by phenylalkyl groups (8, 9a-c, and 10) at C-10, which resulted in the loss of hydroxyl-radical formation, were inactive. On the other hand, decreasing or abolishing the potency of hydroxylradical formation by incorporation of a 10-phenylacyl or 10-phenylalkylidene substituent did not necessarily reduce 5-LO inhibition.

Many 5-LO inhibitors inhibit lipid peroxidation, $, 53,54$ and it is believed that 5-LO inhibition by those substances is due to scavenging of intermediate radicals that are formed within the active site of the enzyme. The most potent 5-LO inhibitors of our series were all effective inhibitors of lipid peroxidation in model membranes. However, examination of the reactivities of the compounds against DPPH in Table I shows the lack of correlation between the ability to intercept a free radical and 5-LO inhibitory potency, suggesting that a simple antioxidant effect does not explain the activity of several inhibitors. The inhibitory effects of these compounds appear to be due to specific enzyme interaction rather than nonspecific redox properties.

The anthralin anion (1a) is the key intermediate in the oxidation process, which involves a one-electron transfer from the anion to oxygen to give the anthralin-10-yl free radical and the active oxygen species. ${ }^{14} 5$-LO contains a non-heme iron that is converted to the ferric form upon activation. ${ }^{55}$ Thus, it may be expected that similar to the oxidation process, electron transfer from the anthralin anion to the active ferric form of 5-LO results in an inactivated enzyme (ferrous form), according to a proposed mechanism. ${ }^{56}$ The so-called redox-active inhibitors are supposed to exert their action by this mechanism. ${ }^{57}$ In addition to the redox properties, other factors such as an appropriate geometry of the molecules when bound to the active site of the enzyme may be responsible for the 5-LO inhibitory activities of the novel anthralin analogs. This is supported by the fact that for these compounds, a definite length of the chain linking the anthrone nucleus and the phenyl rest was optimal for activity.

It has been suggested that the generation of active oxygen species by anthralin is responsible for the inflammation of uninvolved skin. ${ }^{17}$ Hence, inhibitors which lack hydroxyl-radical formation may be expected to be devoid of skin-irritating properties. Furthermore, redox inhibitors are oxidized during their action on LO. ${ }^{58}$ Consequently, their stability is limited. ${ }^{59}$ Indeed, HPLC analysis of the incubation mixtures at the end of the 5-LO assay revealed that anthralin was almost completely degraded to its dimer bianthrone and the corresponding anthraquinone, danthron. Both metabolites are not effective in 5-LO inhibition. ${ }^{22,39}$ Contrary to anthralin, compounds 4p and $7 j$ of our series were not appreciably degraded during the 5-LO assay, and they were not hydrolyzed to anthralin.

In conclusion, we have presented 1,8-dihydroxy-9(10H)anthracenone derivatives (see Tables III and IV for chemical data) which show potent inhibition of 5-LO in bovine PMNL. Several compounds were about a 100-fold more potent than anthralin and butantrone in arachidonic acid 5-LO inhibition, among which were more powerful generators of hydroxyl radicals than anthralin, while some compounds maintained 5-LO inhibitory potency but did not generate hydroxyl radicals. Several compounds are being evaluated as potential antipsoriatic agents devoid of inflammatory and staining effects. 
Table III. Chemical Data of 10-Phenacyl- and 10-Phenylalkylidene-Substituted 1,8-Dihydroxy-9(10H)-anthracenones

\begin{tabular}{|c|c|c|c|c|c|c|}
\hline compd & $\stackrel{\log }{P}$ & formula ${ }^{a}$ & $\begin{array}{c}\mathrm{mp} \\
\left({ }^{\circ} \mathrm{C}\right)\end{array}$ & & & anal. ${ }^{d}$ \\
\hline 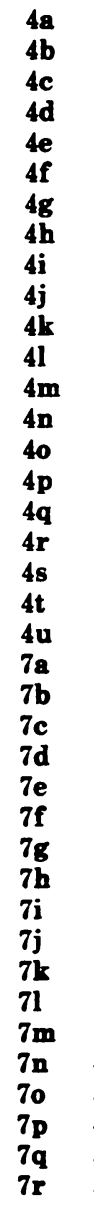 & $\begin{array}{l}4.24 \\
3.96 \\
4.20 \\
5.01 \\
5.43 \\
6.11 \\
5.33 \\
4.63 \\
4.72 \\
4.21 \\
4.06 \\
5.63 \\
4.60 \\
4.23 \\
4.68 \\
4.74 \\
e \\
3.38 \\
3.00 \\
2.61 \\
3.73 \\
5.44 \\
5.83 \\
5.48 \\
4.96 \\
4.58 \\
5.53 \\
5.05 \\
4.85 \\
5.61 \\
5.67 \\
4.38 \\
e \\
e \\
4.40 \\
5.35 \\
4.52 \\
3.94 \\
3.32\end{array}$ & $\begin{array}{l}\mathrm{C}_{22} \mathrm{H}_{16} \mathrm{O}_{4} \\
\mathrm{C}_{22} \mathrm{H}_{16} \mathrm{NO}_{6} \\
\mathrm{C}_{23} \mathrm{H}_{18} \mathrm{O}_{5} \\
\mathrm{C}_{29} \mathrm{H}_{22} \mathrm{O}_{5} \\
\mathrm{C}_{36} \mathrm{H}_{23} \mathrm{O}_{6} \\
\mathrm{C}_{43} \mathrm{H}_{34} \mathrm{O}_{7} \\
\mathrm{C}_{30} \mathrm{H}_{32} \mathrm{O}_{5} \\
\mathrm{C}_{23} \mathrm{H}_{18} \mathrm{O}_{4} \\
\mathrm{C}_{24} \mathrm{H}_{20} \mathrm{O}_{5} \\
\mathrm{C}_{25} \mathrm{H}_{22} \mathrm{O}_{6} \\
\mathrm{C}_{26} \mathrm{H}_{24} \mathrm{O}_{7} \\
\mathrm{C}_{30} \mathrm{H}_{21} \mathrm{O}_{5} \\
\mathrm{C}_{23} \mathrm{H}_{16} \mathrm{O}_{4} \\
\mathrm{C}_{23} \mathrm{H}_{15} \mathrm{NO}_{6} \\
\mathrm{C}_{21} \mathrm{H}_{18} \mathrm{O}_{5} \\
\mathrm{C}_{24} \mathrm{H}_{20} \mathrm{O}_{4} \\
\mathrm{C}_{25} \mathrm{H}_{22} \mathrm{O}_{4} \\
\mathrm{C}_{22} \mathrm{H}_{16} \mathrm{O}_{5} \\
\mathrm{C}_{22} \mathrm{H}_{16} \mathrm{O}_{6} \\
\mathrm{C}_{22} \mathrm{H}_{16} \mathrm{O}_{7} \\
\mathrm{C}_{23} \mathrm{H}_{18} \mathrm{O}_{5} \\
\mathrm{C}_{21} \mathrm{H}_{14} \mathrm{O}_{3} \\
\mathrm{C}_{22} \mathrm{H}_{16} \mathrm{O}_{3} \\
\mathrm{C}_{22} \mathrm{H}_{13} \mathrm{~F}_{3} \mathrm{O}_{3} \\
\mathrm{C}_{21} \mathrm{H}_{13} \mathrm{NO}_{5} \\
\mathrm{C}_{22} \mathrm{H}_{13} \mathrm{NO}_{3} \\
\mathrm{C}_{22} \mathrm{H}_{16} \mathrm{O}_{4} \\
\mathrm{C}_{23} \mathrm{H}_{18} \mathrm{O}_{5} \\
\mathrm{C}_{24} \mathrm{H}_{20} \mathrm{O}_{6} \\
\mathrm{C}_{22} \mathrm{H}_{16} \mathrm{O}_{3} \\
\mathrm{C}_{23} \mathrm{H}_{18} \mathrm{O}_{3} \\
\mathrm{C}_{21} \mathrm{H}_{20} \mathrm{O}_{4} \\
\mathrm{C}_{21} \mathrm{H}_{20} \mathrm{O}_{3} \\
\mathrm{C}_{25} \mathrm{H}_{22} \mathrm{O}_{3} \\
\mathrm{C}_{22} \mathrm{H}_{14} \mathrm{O}_{5} \\
\mathrm{C}_{23} \mathrm{H}_{16} \mathrm{O}_{5} \\
\mathrm{C}_{21} \mathrm{H}_{14} \mathrm{O}_{4} \\
\mathrm{C}_{21} \mathrm{H}_{14} \mathrm{O}_{5} \\
\mathrm{C}_{21} \mathrm{H}_{14} \mathrm{O}_{6}\end{array}$ & $\begin{array}{l}178-179 \\
209-211 \\
169-170 \\
162-163 \\
147-149 \\
124-125 \\
184-186 \\
126-128 \\
108-120 \\
115-118 \\
118-120 \\
140-142 \\
205-108 \\
225^{b} \\
162-166 \\
146-147 \\
128-129 \\
178-179 \\
180^{b} \\
200^{b} \\
190-194 \\
161 \\
146-147 \\
151 \\
172-175 \\
209 \\
165 \\
158 \\
211-212 \\
128-129 \\
143-144 \\
134-136 \\
84-86 \\
59 \\
280 \\
167-168 \\
220-221 \\
216 \\
211-212\end{array}$ & $\begin{array}{r}36 \\
15 \\
45 \\
40 \\
30 \\
15 \\
34 \\
40 \\
17 \\
10 \\
41 \\
36 \\
30 \\
5 \\
36 \\
44 \\
43 \\
70 \\
55 \\
80 \\
45 \\
90 \\
80 \\
65 \\
75 \\
76 \\
85 \\
87 \\
84 \\
55 \\
52 \\
47 \\
65 \\
54 \\
85 \\
58 \\
69 \\
78 \\
60\end{array}$ & $\begin{array}{l}\text { MC/H (7-3) } \\
\text { MC/H (4-1) } \\
\text { MC } \\
\text { MC/H (4-1) } \\
\text { MC/H (7-3) } \\
\text { MC/H (9-1) } \\
\text { MC/H (1-1) } \\
\text { MC/H (7-3) } \\
\text { MC } \\
\text { MC } \\
\text { MC } \\
\text { MC/H (3-2) } \\
\text { MC/H (3-2) } \\
\text { MC } \\
\text { MC/H (3-2) } \\
\text { MC/H (7-3) } \\
\text { MC/H (7-3) } \\
\text { MC/E (3-2) } \\
\text { MC/E (4-1) } \\
\text { MC/M (19-1) } \\
\text { MC/EA (4-1) } \\
\text { MC } \\
\text { MC } \\
\text { P/E (4-1) } \\
\mathrm{P} / \mathrm{EA} \mathrm{(7-3)} \\
\text { MC } \\
\text { MC } \\
\text { MC } \\
\text { MC } \\
\text { MC } \\
\text { P/EA (7-3) } \\
\text { MC } \\
\text { MC } \\
\text { MC } \\
\text { MC } \\
\text { MC/E (9-1) } \\
\text { MC/E (3-7) } \\
\text { E }\end{array}$ & 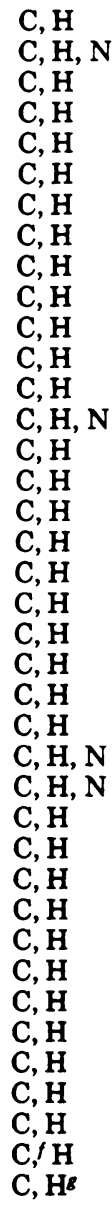 \\
\hline
\end{tabular}

a All new compounds displayed ${ }^{1} \mathrm{H}-\mathrm{NMR}$, FTIR, UV, and MS spectra consistent with the assigned structure. ${ }^{b}$ Decomposition. ${ }^{c} \mathbf{E}$ = ether, $\mathrm{EA}=$ ethyl acetate, $\mathrm{H}=$ hexane, $\mathrm{M}=$ methanol, $\mathrm{MC}=$ methylene chloride, and $\mathrm{P}=$ petroleum ether $(40-60)$. ${ }^{d}$ Elemental analyses were within $\pm 0.4 \%$ of calculated values except where stated otherwise. ' Not determined. $f$ C: calcd, 72.83; found, 71.36. $8 \mathrm{H}$ : calcd, 3.89; found, 4.74 .

\section{Experimental Section}

Melting points were determined with a Bũchi 510 melting point apparatus and are uncorrected. Chromatography refers to column chromatography on silica gel (E. Merck, 70-230 mesh). In most cases, the concentrated crude products obtained by chromatography using the indicated eluants (Tables IIIand IV) were treated with a small amount of herane to induce precipitation. 'H NMR spectra were recorded with a Varian EM 390 (90 MHz) or a Bruker Spectrospin WM 250 spectrometer (250 $\mathrm{MHz}$ ), using tetramethylsilane as an internal standard. Fouriertransform IR spectra $(\mathrm{KBr})$ were recorded on a Nicolet $510 \mathrm{M}$ FTIR spectrometer. Mass spectra (EI, unless otherwise stated) were obtained on a Varian MAT CH5 spectrometer $(70 \mathrm{eV})$. HPLC (Kontron 420, 735 LC UV detector) was performed on a $250-x$ 4-mm column packed with Nucleosil $C_{18}$ (7- $\mu$ m particles; Bischoff, Leonberg, Germany).

Preparation of Acyl Chlorides. Acyl chlorides were prepared from the corresponding acids ${ }^{60,61}$ by following standard literature procedures. ${ }^{36,36}$ In most cases, the crude products were used in the subsequent acylation steps.

General Procedure for the Preparation of 1,8-Dihydroxy10-(1-0xo- $\omega$-phenylalkyl)-9(10H)-anthracenones 4a-q. 1,8Dihydroxy-10-(1-oxo-4-phenylbutyl)-9(10B)-anthracenone (4p). To a solution of anthralin ${ }^{62}(1,1.13 \mathrm{~g}, 5 \mathrm{mmol})$ in absolute toluene $(80 \mathrm{~mL})$ and dry pyridine $(0.55 \mathrm{~mL}, 7 \mathrm{mmol})$ was added dropwise a solution of phenylbutyryl chloride ${ }^{63}(1.30$ $\mathrm{g}, 7 \mathrm{mmol})$ in absolute toluene $(10 \mathrm{~mL})$ under $\mathrm{N}_{2}$. The reaction mixture was heated to $80^{\circ} \mathrm{C}$ for $3 \mathrm{~h}$ (the reaction mirture was stirred at room temperature for compounds $4 \mathrm{~b}, 4 \mathrm{~d}, 4 \mathrm{e}-\mathrm{g}$, and 4m-o), cooled, and filtered, and the filtrate was evaporated. The residue was purified by chromatography. Recrystallization from toluene/herane gave yellow needles (Table III): ${ }^{1} \mathrm{H} \mathrm{NMR}$ ( $\mathrm{CDCl}_{3}$ ) $\delta 12.25(\mathrm{~s}, 2 \mathrm{H}), 7.65-6.85(\mathrm{~m}, 11 \mathrm{H}), 5.25(\mathrm{~s}, 1 \mathrm{H}), 2.40-1.95 \mathrm{(m}$, 4H), 1.80-1.55 (m, 2H); FTIR 1713 (CO), $1632 \mathrm{~cm}^{-1}$ (CO-HO); MS $m / z 372$ (2). Anal. $\left(\mathrm{C}_{24} \mathrm{H}_{20} \mathrm{O}_{4}\right): \mathrm{C}, \mathrm{H}$.

General Procedure for the Hydrogenolytic Cleavage of Benzyl Ethers 4r-u. 1,8-Dihydroxy-10-[2-(3,4,5-trihydroxyphenyl)-1-oxoethyl]-9(10H)-anthracenone (4t). A solution of $4 \mathrm{f}(0.5 \mathrm{~g}, 0.75 \mathrm{mmol})$ in absolute THF $(50 \mathrm{~mL})$ was hydrogenated over $10 \% \mathrm{Pd}-\mathrm{C}(150 \mathrm{mg})$ at room temperature and atmospheric pressure. After the requisite amount of hydrogen had been taken up ( $24 \mathrm{~h}$, TLC control), the catalyst was removed by filtration and the solution was evaporated. The product was purified by chromatography. Recrystallization from absolute ethanol afforded yellow crystals (Table III): ${ }^{1} \mathrm{H}$ NMR (DMSO- $d_{6}$ ) $\delta 11.89$ $(\mathrm{s}, 2 \mathrm{H}), 8.77(\mathrm{~s}, 3 \mathrm{H}), 7.61-6.93(\mathrm{~m}, 6 \mathrm{H}), 6.00(\mathrm{~s}, 2 \mathrm{H}), 5.70(\mathrm{~s}, 1 \mathrm{H})$, 3.73 (s, 2H); FTIR 3432 (OH), 1696 (CO), $1634 \mathrm{~cm}^{-1}$ (CO-HO); MS $m / z 392$ (5). Anal. $\left(\mathrm{C}_{22} \mathrm{H}_{16} \mathrm{O}_{7}\right)$ : C, $\mathrm{H}$.

Preparation of $\alpha$-Chloro Methyl Ethers 5a-m. The appropriate aldehydes were converted to the corresponding dimethyl acetals and then to the $\alpha$-chloro methyl ethers according to literature procedures. 64,65

General Procedure for the Preparation of 1,8-Dihydroxy10-(1-methoxy- $\omega$-phenylalkyl)-9(10H)-anthracenones 6a-m. 1,8-Dihydroxy-10-(1-methoxy-3-phenylpropyl)-9(10B)-anthracenone (6j). To a solution of $1(0.99 \mathrm{~g}, 4.4 \mathrm{mmol})$ and DBU $(0.7 \mathrm{~g}, 4.6 \mathrm{mmol})$ in dry $\mathrm{CH}_{2} \mathrm{Cl}_{2}(50 \mathrm{~mL})$ was added dropwise at $0{ }^{\circ} \mathrm{C}$ a solution of (3-chloro-3-methoxypropyl)benzene $(1.02 \mathrm{~g}$, $5.5 \mathrm{mmol}$ ), which was in turn prepared from (3,3-dimethoxypropyl) benzene, ${ }^{66}$ in dry $\mathrm{CH}_{2} \mathrm{Cl}_{2}(10 \mathrm{~mL})$, and the solution was allowed to stir at $0^{\circ} \mathrm{C}$ for $30 \mathrm{~min}$ under $\mathrm{N}_{2}$. The reaction mixture was shaken thoroughly with $2 \mathrm{~N} \mathrm{HCl}$, and the organic phase was washed with saturated aqueous $\mathrm{NaCl}$, dried over $\mathrm{Na}_{2} \mathrm{SO}_{4}$, and evaporated. The residue was purified by chromatography. Recrystallization from absolute ethanol gave yellow crystals (Table IV): ${ }^{1} \mathrm{H}$ NMR $\left(\mathrm{CDCl}_{3}\right) \delta 12.22(\mathrm{~s}, 1 \mathrm{H}), 12.20(\mathrm{~s}, 1 \mathrm{H}), 7.60-$ $6.75(\mathrm{~m}, 11 \mathrm{H}), 4.45(\mathrm{~d}, 1 \mathrm{H}, J=4 \mathrm{~Hz}), 3.45(\mathrm{~s}, 3 \mathrm{H}), 3.40-3.25(\mathrm{~m}$, $1 \mathrm{H}), 2.65-2.25(\mathrm{~m}, 2 \mathrm{H}), 1.40-1.10(\mathrm{~m}, 2 \mathrm{H})$; FTIR $1632 \mathrm{~cm}^{-1}$ (CO $\mathrm{HO}$ ); MS $m / z 374(0.2)$. Anal. $\left(\mathrm{C}_{24} \mathrm{H}_{22} \mathrm{O}_{4}\right): \mathrm{C}, \mathrm{H}$.

1,8-Dihydroxy-10-(2-phenylethylidene)-9(10H)-anthracenone (7i). A suspension of $6 \mathrm{i}(0.5 \mathrm{~g}, 1.39 \mathrm{mmol})$ in absolute methanol $(10 \mathrm{~mL})$ was treated with DBU $(1.1 \mathrm{~g}, 7.23 \mathrm{mmol})$. The reaction was terminated exactly after $3 \mathrm{~min}$ by the addition of excess $6 \mathrm{~N} \mathrm{HCl}$. The reaction mirture was shaken thoroughly and extracted with $\mathrm{CH}_{2} \mathrm{Cl}_{2}$. The organic phase was dried over $\mathrm{Na}_{2} \mathrm{SO}_{4}$ and then evaporated. The residue was purified by chromatography to afford 7i as yellow crystals (Table III, 97\% isomerically pure by HPLC analysis with respect to 8): ${ }^{1} \mathrm{H}$ NMR $\left(250 \mathrm{MHz}_{1} \mathrm{CDCl}_{3}\right) \delta 12.37(\mathrm{~s}, 1 \mathrm{H}), 12.22(\mathrm{~s}, 1 \mathrm{H}), 7.65-6.90(\mathrm{~m}$, $11 \mathrm{H}), 6.68(\mathrm{t}, 1 \mathrm{H}, J=7.4 \mathrm{~Hz}), 3.95(\mathrm{~d}, 2 \mathrm{H}, J=7.4 \mathrm{~Hz})$; FTIR $1630 \mathrm{~cm}^{-1}$ (CO HO); MS m/z 328 (74). Anal. $\left(\mathrm{C}_{22} \mathrm{H}_{16} \mathrm{O}_{3}\right): \mathrm{C}, \mathrm{H}$.

General Procedure for the Preparation of 1,8-Dihydroxy10-( $\omega$-phenylalkylidene)-9(10H)-anthracenones $7 \mathrm{a}-\mathrm{h}$ and $7 \mathrm{j}$ m. 1,8-Dihydroxy-10-(3-phenylpropylidene)-9(10H)-anthracenone (7j). A solution of $6 \mathrm{j}(0.5 \mathrm{~g}, 1.33 \mathrm{mmol})$ in pyridine $(10$ $\mathrm{mL}$ ) was refluxed under $\mathrm{N}_{2}$ for 15-30 min until the reaction was completed (TLC control). The reaction mixture was then cooled and poured into water $(200 \mathrm{~mL})$, acidified with $6 \mathrm{~N} \mathrm{HCl}$, and extracted with $\mathrm{CH}_{2} \mathrm{Cl}_{2}(3 \times 20 \mathrm{~mL})$. The combined $\mathrm{CH}_{2} \mathrm{Cl}_{2}$ extracts were washed with saturated aqueous $\mathrm{NaCl}$, dried over $\mathrm{Na}_{2} \mathrm{SO}_{4}$, and then evaporated. The residue was purified by chromatography to afford yellow crystals (Table III): ${ }^{1} \mathrm{H}$ NMR $\left(\mathrm{CDCl}_{3}\right) \delta 12.30(\mathrm{~s}, 1 \mathrm{H}), 12.20(\mathrm{~s}, 1 \mathrm{H}), 7.60-6.40(\mathrm{~m}, 12 \mathrm{H}), 2.85$ (s, 4H); FTIR $1630 \mathrm{~cm}^{-1}$ (CO $\left.\mathrm{HO}\right) ; \mathrm{MS} \mathrm{m} / 2342$ (25). Anal. $\left(\mathrm{C}_{23} \mathrm{H}_{18} \mathrm{O}_{3}\right): \mathrm{C}, \mathrm{H}$.

10-[(4-Carboxyphenyl)methylene]-1,8-dihydroxy-9(10H)anthracenone $(7 \mathrm{n})$. A suspension of $7 \mathrm{e}(0.5 \mathrm{~g}, 1.47 \mathrm{mmol})$ in $50 \%$ sulfuric acid $(40 \mathrm{~mL})$ and glacial acetic acid $(40 \mathrm{~mL})$ was refluxed for $24 \mathrm{~h}$. The reaction mixture was cooled in an ice bath, and the resulting crystals were filtered by suction and washed thoroughly with water, then with a small amount of cold 
Table IV. Chemical Data of 10-Phenylalkyl-Substituted 1,8-Dihydroxy-9(10H)-anthracenones

\begin{tabular}{|c|c|c|c|c|c|c|c|c|}
\hline compd & $\mathbf{R}^{\mathbf{1}}$ & $\mathrm{X}$ & $\mathbf{R}^{2}$ & formula ${ }^{a}$ & $\mathrm{mp}\left({ }^{\circ} \mathrm{C}\right)$ & yield $(\%)$ & chromatography solvent (vol \%) & anal.d \\
\hline $\begin{array}{c}6 \mathbf{a} \\
6 \mathbf{b} \\
6 \mathbf{c} \\
6 \mathbf{d} \\
6 \mathbf{e} \\
6 \mathbf{f} \\
6 \mathbf{g} \\
6 \mathbf{h} \\
6 \mathbf{i} \\
6 \mathbf{j} \\
6 \mathbf{k} \\
6 \mathbf{l} \\
6 \mathbf{m} \\
8 \\
9 \mathbf{a} \\
9 \mathbf{b} \\
9 \mathbf{c} \\
10\end{array}$ & $\begin{array}{l}\mathrm{H} \\
\mathrm{H} \\
\mathrm{H} \\
\mathrm{H} \\
\mathrm{H} \\
\mathrm{H} \\
\mathrm{H} \\
\mathrm{H} \\
\mathrm{H} \\
\mathrm{H} \\
\mathrm{H} \\
\mathrm{H} \\
\mathrm{H} \\
\mathrm{H} \\
\mathrm{H} \\
\mathrm{H} \\
\mathrm{H} \\
\mathrm{CH} \\
\mathrm{C} \\
\mathrm{Ph}\end{array}$ & $\begin{array}{l}\mathrm{CH}\left(\mathrm{OCH}_{3}\right) \\
\mathrm{CH}\left(\mathrm{OCH}_{3}\right) \\
\mathrm{CH}\left(\mathrm{OCH}_{3}\right) \\
\mathrm{CH}\left(\mathrm{OCH}_{3}\right) \\
\mathrm{CH}\left(\mathrm{OCH}_{3}\right) \\
\mathrm{CH}\left(\mathrm{OCH}_{3}\right) \\
\mathrm{CH}\left(\mathrm{OCH}_{3}\right) \\
\mathrm{CH}\left(\mathrm{OCH}_{3}\right) \\
\mathrm{CH}\left(\mathrm{OCH}_{3}\right) \mathrm{CH}_{2} \\
\mathrm{CH}\left(\mathrm{OCH}_{3}\right)\left(\mathrm{CH}_{2}\right)_{2} \\
\mathrm{CH}\left(\mathrm{OCH}_{3}\right)\left(\mathrm{CH}_{2}\right)_{3} \\
\mathrm{CH}\left(\mathrm{OCH}_{3}\right)\left(\mathrm{CH}_{2}\right)_{3} \\
\mathrm{CH}\left(\mathrm{OCH}_{3}\right)\left(\mathrm{CH}_{2}\right)_{4} \\
\mathrm{CH}=\mathrm{CH} \\
\mathrm{CH} \\
\mathrm{CH}_{2} \\
\mathrm{CH}_{2} \\
\mathrm{CH}_{2}\end{array}$ & $\begin{array}{l}\mathrm{H} \\
4-\mathrm{CH}_{3} \\
4-\mathrm{CF}_{3} \\
4-\mathrm{NO}_{2} \\
4-\mathrm{CN} \\
4-\mathrm{OCH}_{3} \\
3,4-\left(\mathrm{OCH}_{3}\right)_{2} \\
3,4,5-\left(\mathrm{OCH}_{3}\right)_{2} \\
\mathrm{H} \\
\mathrm{H} \\
4-\mathrm{OCH}_{3} \\
\mathrm{H} \\
\mathrm{H} \\
\mathrm{H} \\
\mathrm{H} \\
\text { 4-NO } \\
\text { 4-OCH } \\
\mathrm{H}\end{array}$ & $\begin{array}{l}\mathrm{C}_{22} \mathrm{H}_{18} \mathrm{O}_{4} \\
\mathrm{C}_{23} \mathrm{H}_{20} \mathrm{O}_{4} \\
\mathrm{C}_{23} \mathrm{H}_{17} \mathrm{~F}_{3} \mathrm{O}_{4} \\
\mathrm{C}_{22} \mathrm{H}_{17} \mathrm{NO}_{6} \\
\mathrm{C}_{23} \mathrm{H}_{17} \mathrm{NO}_{4} \\
\mathrm{C}_{23} \mathrm{H}_{20} \mathrm{O}_{5} \\
\mathrm{C}_{24} \mathrm{H}_{22} \mathrm{O}_{6} \\
\mathrm{C}_{25} \mathrm{H}_{24} \mathrm{O}_{7} \\
\mathrm{C}_{23} \mathrm{H}_{22} \mathrm{O}_{4} \\
\mathrm{C}_{24} \mathrm{H}_{22} \mathrm{O}_{4} \\
\mathrm{C}_{25} \mathrm{H}_{24} \mathrm{O}_{5} \\
\mathrm{C}_{25} \mathrm{H}_{24} \mathrm{O}_{4} \\
\mathrm{C}_{26} \mathrm{H}_{26} \mathrm{O}_{4} \\
\mathrm{C}_{22} \mathrm{H}_{16} \mathrm{O}_{3} \\
\mathrm{C}_{21} \mathrm{H}_{16} \mathrm{O}_{3} \\
\mathrm{C}_{21} \mathrm{H}_{15} \mathrm{NO}_{5} \\
\mathrm{C}_{22} \mathrm{H}_{18} \mathrm{O}_{4} \\
\mathrm{C}_{25} \mathrm{H}_{22} \mathrm{O}_{3}\end{array}$ & $\begin{array}{l}162-163 \\
137-138 \\
155-156 \\
175-177 \\
165-166 \\
133-134 \\
144-146 \\
130-131 \\
140-141 \\
138-139 \\
83-85 \\
128-130 \\
68 \\
186 \\
119 b \\
190-192 \\
135-136 \\
205-206\end{array}$ & $\begin{array}{l}40 \\
33 \\
40 \\
40 \\
40 \\
37 \\
32 \\
32 \\
20 \\
18 \\
42 \\
25 \\
17 \\
64 \\
20 \\
45 \\
20 \\
22\end{array}$ & $\begin{array}{l}\text { MC/H (9-11) } \\
M C / H(1-1) \\
\text { P/E (4-1) } \\
\text { P/E (4-1) } \\
\text { MC/H (9-1) } \\
\text { MC/H (4-1) } \\
\text { P/EA (13-7) } \\
\text { P/EA (13-7) } \\
\text { MC } \\
\text { MC } \\
\text { MC } \\
\text { MC/H (7-3) } \\
\text { MC/H (7-3) } \\
\text { MC } \\
\text { P/EA (16-3) } \\
\text { P/EA (6-3) } \\
\text { MC/H (4-1) } \\
\text { MC/H (4-1) }\end{array}$ & $\begin{array}{l}\text { C, H } \\
\text { C, H } \\
\text { C, H } \\
\text { C, H, N } \\
\text { C, H, N } \\
\text { C, H } \\
\text { C, H } \\
\text { C, H } \\
\text { C, H } \\
\text { C, H } \\
\text { C, H } \\
\text { C, H } \\
\text { C, H } \\
\text { C, H } \\
\text { C, H } \\
\text { C, H, N } \\
\text { C, H } \\
\text { C, H }\end{array}$ \\
\hline
\end{tabular}

a-d See footnotes of Table III.

methanol, and then with petroleum ether $(40-60)$ to afford a yellow powder (Table III): ${ }^{1} \mathrm{H}$ NMR (DMSO- $\left.d_{6}\right) \delta 12.10(\mathrm{~s}, 1 \mathrm{H})$, $12.00(\mathrm{~s}, 1 \mathrm{H}), 7.95-6.85(\mathrm{~m}, 11 \mathrm{H})$; FTIR $1681(\mathrm{COOH}), 1630 \mathrm{~cm}^{-1}$ (CO-HO); MS m/2 358 (82). Anal. $\left(\mathrm{C}_{22} \mathrm{H}_{14} \mathrm{O}_{5}\right)$ : C, $\mathrm{H}$.

1,8-Dihydroxy-10-[ (4-(methoxycarbonyl)phenyl)methylene]-9(10B)-anthracenone (70). A suspension of $7 n$ $(0.5 \mathrm{~g}, 1.40 \mathrm{mmol})$ in absolute methanol $(160 \mathrm{~mL})$ and $96 \%$ sulfuric acid $(0.5 \mathrm{~mL})$ was refluxed for $24 \mathrm{~h}$. The reaction mixture was cooled to $-20^{\circ} \mathrm{C}$, and the resulting crystals were filtered by suction. Purification by chromatography gave orange-yellow crystals (Table III): ${ }^{1} \mathrm{H}$ NMR $\left(\mathrm{CDCl}_{3}\right) \delta 12.30$ (s, $\left.1 \mathrm{H}\right), 12.20$ (s, $1 \mathrm{H}), 8.10-6.90(\mathrm{~m}, 11 \mathrm{H}), 3.95(\mathrm{~s}, 3 \mathrm{H})$; FTIR $1717\left(\mathrm{CO}_{2} \mathrm{CH}_{3}\right), 1630$ $\mathrm{cm}^{-1}$ (CO-HO); $\mathrm{MS} \mathrm{m} / 2372$ (80). Anal. $\left(\mathrm{C}_{23} \mathrm{H}_{16} \mathrm{O}_{5}\right): \mathrm{C}, \mathrm{H}$.

General Procedure for the Cleavage of Methyl Ethers 7p-r. 1,8-Dihydroxy-10-[(4-hydroxyphenyl)methylene]$9(10 \mathrm{H})$-anthracenone (7p). A solution of $7 \mathrm{f}(0.5 \mathrm{~g}, 1.45 \mathrm{mmol})$ in dry $\mathrm{CH}_{2} \mathrm{Cl}_{2}(10 \mathrm{~mL})$ was added dropwise to a solution of $\mathrm{BBr}_{3}$ $(0.72 \mathrm{~mL}, 7.26 \mathrm{mmol})$ in $\mathrm{CH}_{2} \mathrm{Cl}_{2}(20 \mathrm{~mL})$ at $-70^{\circ} \mathrm{C}$ under $\mathrm{N}_{2}$. The mixture was allowed to warm to room temperature and stirred for $24 \mathrm{~h}$. Excess water was added, and the mixture was extracted with ether. The ether phase was dried and evaporated and the residue purified by chromatography to afford $7 \mathbf{p}$ as orange-red crystals (Table III): ${ }^{1} \mathrm{H}$ NMR (DMSO- $\left.d_{6}\right) \delta 12.15(\mathrm{~s}, 1 \mathrm{H}), 12.00$ (s, 1H), $9.80(\mathrm{~s}, 1 \mathrm{H}), 7.70-6.60(\mathrm{~m}, 1 \mathrm{H})$; FTIR $3423(\mathrm{OH}), 1630$ $\mathrm{cm}^{-1}$ (CO HO); MS m/z 330 (100). Anal. $\left(\mathrm{C}_{21} \mathrm{H}_{14} \mathrm{O}_{4}\right): \mathrm{C}, \mathrm{H}$.

(E)-1,8-Dihydroxy-10-(2-phenylethenyl)-9(10H)-anthracenone (8). A suspension of $6 \mathrm{i}(0.5 \mathrm{~g}, 1.39 \mathrm{mmol})$ in absolute methanol $(10 \mathrm{~mL})$ was treated with DBU $(1.1 \mathrm{~g}, 7.23 \mathrm{mmol})$. The mirture was stirred at room temperature for $10 \mathrm{~h}$, under $\mathrm{N}_{2}$ and protected from light, until the reaction was completed by TLC analysis on silica gel RP-18, methanol/water/acetic acid (9-10.1 ). The reaction mixture was shaken thoroughly with excess $2 \mathrm{~N} \mathrm{HCl}$ and extracted with $\mathrm{CH}_{2} \mathrm{Cl}_{2}$. The organic phase was dried over $\mathrm{Na}_{2} \mathrm{SO}_{4}$ and then evaporated. The residue was purified by chromatography to afford 8 as yellow crystals (Table IV, $64 \%$, $>99 \%$ isomerically pure by HPLC analysis with respect to $7 \mathbf{i}$ ): ${ }^{1} \mathrm{H} \mathrm{NMR}\left(\mathrm{CDCl}_{3}\right) \delta 12.30(\mathrm{~s}, 2 \mathrm{H}), 7.55-6.85(\mathrm{~m}, 11 \mathrm{H}), 6.59(\mathrm{~d}, 1 \mathrm{H}$, $J=15 \mathrm{~Hz}), 6.06$ (dd, $1 \mathrm{H}, J=15 / 9 \mathrm{~Hz}), 4.90(\mathrm{~d}, 1 \mathrm{H}, J=9 \mathrm{~Hz})$; FTIR $1632 \mathrm{~cm}^{-1}$ (CO-HO); $\mathrm{MS} \mathrm{m} / z 328$ (99). Anal. $\left(\mathrm{C}_{22} \mathrm{H}_{16} \mathrm{O}_{3}\right)$ : $\mathrm{C}, \mathrm{H}$.

General Proced ure for the Preparation of 1,8-Dihydroxy10-( $\omega$-phenylalkyl)-9(10B)-anthracenones 9a-c. 1,8-Dihydroxy-10-(phenylmethyl)-9(10B)-anthracenone (9a). Anthralin $(1,1 \mathrm{~g}, 4.42 \mathrm{mmol})$ and dry $\mathrm{Na}_{2} \mathrm{CO}_{3}(1.25 \mathrm{~g})$ were suspended in absolute acetone $(60 \mathrm{~mL})$ under $\mathrm{N}_{2}$. Benzyl chloride $(0.62 \mathrm{~g}$,
$4.90 \mathrm{mmol}$ ) and catalytic amounts of potassium iodide were added, and the mixture was refluxed for $15 \mathrm{~h}$ under $\mathrm{N}_{2}$. Then the mirture was cooled, treated with water and $2 \mathrm{~N}$ sulfuric acid, and extracted exhaustively with $\mathrm{CH}_{2} \mathrm{Cl}_{2}$. The combined organic extracts were washed with water, dried over $\mathrm{Na}_{2} \mathrm{SO}_{4}$, and then evaporated. The residue was purified by chromatography to afford $9 \mathrm{a}$ as yellow crystals (Table IV): ${ }^{1} \mathrm{H}$ NMR $\left(\mathrm{CDCl}_{3}\right) \delta 11.95(\mathrm{~s}, 2 \mathrm{H}), 7.50-6.30$ $(\mathrm{m}, 11 \mathrm{H}), 4.45(\mathrm{t}, 1 \mathrm{H}, J=6 \mathrm{~Hz}), 3.05$ (d, $2 \mathrm{H}, J=6 \mathrm{~Hz})$; FTIR $1634 \mathrm{~cm}^{-1}$ (CO-HO); $\mathrm{MS} \mathrm{m} / z 316$ (24). Anal. $\left(\mathrm{C}_{21} \mathrm{H}_{16} \mathrm{O}_{3}\right): \mathrm{C}, \mathrm{H}$.

1,8-Dihydroxy-10,10-bis(phenylmethyl)-9(10B)-anthracenone (10). 10 was prepared from $1(2 \mathrm{~g}, 8.84 \mathrm{mmol})$, benzyl chloride $(2.8 \mathrm{~g}, 22.12 \mathrm{mmol})$, and dry $\mathrm{Na}_{2} \mathrm{CO}_{3}(6 \mathrm{~g})$ as described for $9 \mathrm{a}$, but the reflux was maintained for $6 \mathrm{~h}$. 10 was obtained as yellow crystals (Table IV): ${ }^{1} \mathrm{H} \mathrm{NMR}\left(\mathrm{CDCl}_{3}\right) \delta 12.30(\mathrm{~s}, 2 \mathrm{H})$, 7.75-6.30 (m, 16H), 3.65 (s, 4H); FTIR $1638 \mathrm{~cm}^{-1}$ (CO-HO); MS $m / z 406$ (22). Anal. $\left(\mathrm{C}_{23} \mathrm{H}_{22} \mathrm{O}_{3}\right): \mathrm{C}, \mathrm{H}$.

$\log P$ Determination. ${ }^{45}$ The method is based on the linear relationship between the capacity factors $\log k^{\prime}$ of the compounds and their $\log P$ values. The $\log k^{\prime}$ values of five compounds (4-nitrophenol, 4-chlorophenol, benzophenone, naphthalene, and anthracene) with known $\log P$ values $(1.91,2.39,3.18,3.44$, and 4.49 , respectively) were determined. A plot of $\log k^{\prime}$ versus $\log$ $P$ generated from this calibration mixture was used for the calculation of $\log P$ values for unknowns from the logarithms of their chromatographic capacity factors (correlation coefficient $>0.99 ; n=3$ ). Methanol/water/acetic acid (77-23-0.1), adjusted to $\mathrm{pH} 5.5$ with concentrated $\mathrm{NH}_{3}$, was used as eluant.

Determination of the Reducing Activitiy against 2,2Diphenyl-1-picrylhydrazyl.$^{19}$ To $1 \mathrm{~mL}$ of the test compound solution $\left(10^{-4} \mathrm{M}\right)$ was added $1 \mathrm{~mL}$ of DPPH solution $\left(10^{-4} \mathrm{M}\right)$, each in acetone/PBS (1-1 v/v), and the reduction of DPPH was followed spectrophotometrically at $516 \mathrm{~nm}$. Plots of the reciprocal of DPPH concentrations against time gave straight lines, and the second-order rate constants were obtained from the slopes and are expressed as mean values $(n=3-6)$.

Degradation of 2-Deoxy-D-ribose. ${ }^{19}$ The following reagents were added to glass tubes in the order and at the final concentrations stated: $0.3 \mathrm{~mL}$ of $\mathrm{KH}_{2} \mathrm{PO}_{4}-\mathrm{KOH}$ buffer, $\mathrm{pH} 7.4$ (30 mM), $0.2 \mathrm{~mL}$ of $\mathrm{H}_{2} \mathrm{O}$ (double distilled), $0.2 \mathrm{~mL}$ of 2-deoryD-ribose $(2 \mathrm{mM}), 0.2 \mathrm{~mL}$ of $\mathrm{FeCl}_{3} \cdot 6 \mathrm{H}_{2} \mathrm{O}(0.1 \mathrm{mM})$, and $0.1 \mathrm{~mL}$ of anthracenone derivative $(75 \mu \mathrm{M})$. Stock solutions of the compounds were made up fresh before use. Appropriate blanks and controls with the vehicle (acetonitrile) were conducted. The reaction mixtures were incubated for $2 \mathrm{~h}$ at $37^{\circ} \mathrm{C}$ in a shaking water bath. Trichloroacetic acid $(1.0 \mathrm{~mL}, 2.8 \%$ w/v) and $1.0 \mathrm{~mL}$ 
of $1 \%(w / v$ in $0.05 \mathrm{~N} \mathrm{NaOH})$ 2-thiobarbituric acid (TBA) were added, and the samples were heated at $100^{\circ} \mathrm{C}$ for $15 \mathrm{~min}$ and then cooled in an ice bath $(5 \mathrm{~min})$. Then, $2.0 \mathrm{~mL}$ of the reaction mixtures was treated with $0.05 \mathrm{~mL}$ of $36 \%(\mathrm{w} / \mathrm{v}) \mathrm{HCl}$ and $2.0 \mathrm{~mL}$ of 1-butanol, and the mixtures were vigorously shaken in a vortex mixer (Heidolph) for $15 \mathrm{~s}$. The organic layer was separated by centrifugation at $1500 \mathrm{~g}(15 \mathrm{~min})$, and the absorbance at $532 \mathrm{~nm}$ was measured against butanol. Calibration was performed using a malondialdehyde standard prepared by hydrolysis of $1,1,3,3$,tetraethoxypropane. ${ }^{67}$ TBA-reactive material is expressed in terms of $\mu \mathrm{mol}$ of $\mathrm{MDA} / \mathrm{mmol}$ deoxyribose.

Assay of Lipid Peroxidation in Bovine Brain Phospholipid Liposomes. Bovine brain phospholipids were prepared essentially as described by Gutteridge. ${ }^{51}$ They were weighed into glass tubes and shaken in a vortex mixer (Heidolph) in the presence of five small glass beads (o.d. $4 \mathrm{~mm}$ ) for $1 \mathrm{~min}$. The phospholipids were suspended in $0.15 \mathrm{M} \mathrm{NaCl}, \mathrm{pH} 7.4$, to a final concentration of $5 \mathrm{mg} / \mathrm{mL}$. The mixture was purged with $\mathrm{N}_{2}$ for $1 \mathrm{~min}$ and vigorously dispersed in a vortex mixer for $5 \mathrm{~min}$. The liposomes were allowed to swell for $1 \mathrm{~h}$ at $4^{\circ} \mathrm{C}$.

The following reagents were added to glass tubes in the order and at the final concentrations stated: $0.3 \mathrm{~mL}$ of $\mathrm{KH}_{2} \mathrm{PO}_{4}-\mathrm{KOH}$ buffer, pH $7.4(30 \mathrm{mM}), 0.19 \mathrm{~mL}$ of $\mathrm{H}_{2} \mathrm{O}$ (double distilled), 0.2 $\mathrm{mL}$ of liposomes $(1 \mathrm{mg} / \mathrm{mL}), 0.2 \mathrm{~mL}$ of $\mathrm{FeCl}_{3} \cdot 6 \mathrm{H}_{2} \mathrm{O}(0.1 \mathrm{mM}), 0.1$ $\mathrm{mL}$ of ascorbic acid $(0.1 \mathrm{mM})$, and $0.01 \mathrm{~mL}$ of anthracenone derivative (variable concentrations). Appropriate blanks and controls with the vehicles (acetone) were conducted. The reaction mixtures were incubated for $1 \mathrm{~h}$ at $37^{\circ} \mathrm{C}$ in a shaking water bath. BHT $(10 \mu \mathrm{L}, 20 \% \mathrm{w} / \mathrm{v}), 0.5 \mathrm{~mL}$ of $25 \%(\mathrm{w} / \mathrm{v}) \mathrm{HCl}$, and $0.5 \mathrm{~mL}$ of $1 \%$ 2-thiobarbituric acid were added, and TBA-reactive material was measured as described above.

Bovine PMNL 5-Lipoxygenase Assay. PMNL were prepared essentially as described from sodium EDTA-anticoagulated bovine blood. ${ }^{37}$ Contaminating platelets were removed by repeated centrifugations at $100 \mathrm{~g}$ for $20 \mathrm{~min}$. The purified PMNL were suspended at a concentration of $1 \times 10^{7}$ cells $/ \mathrm{mL}$ in phosphate-buffered saline (PBS, adjusted to $\mathrm{pH} 7.4$ with $3 \mathrm{~N}$ $\mathrm{NH}_{3}$ in a final volume of $1000 \mathrm{~mL}$ of double-distilled $\mathrm{H}_{2} \mathrm{O}$ ). Cell counts were conducted with a Sysmex microcell counter CC-130. Preincubation was performed with $2.4 \mathrm{~mL}$ of the suspension and $10 \mu \mathrm{L}$ of a DMSO stock solution of the test compounds in PBS or vehicle control (DMSO at a final concentration of $0.4 \%$ ) for $15 \mathrm{~min}$ at $37^{\circ} \mathrm{C}$ in a shaking water bath. $\mathrm{CaCl}_{2}$ and $\mathrm{Ca}$ ionophore A23187 (final concentrations $2 \mathrm{mM}$ and $20 \mu \mathrm{M}$, respectively) were added, and the incubation was conducted for $10 \mathrm{~min}$ at 37 ${ }^{\circ} \mathrm{C}$. 5-LO product formation was terminated by the addition of $3.0 \mathrm{~mL}$ of methanol/acetonitrile (1-1) containing NDGA as a radical scavenger (final concentration $0.01 \mathrm{mM}$ ) and prostaglandin $\mathrm{B}_{2}$ as a chromatographic marker (final concentration 0.3 $\mu \mathrm{M})$. The incubation mirture was kept in an ice bath for $20 \mathrm{~min}$ and then centrifuged at $4000 \mathrm{~g}$ for $5 \mathrm{~min}$ at $0^{\circ} \mathrm{C}$. The supernatant was diluted with $5 \mathrm{~mL}$ of water and passed through a prewashed (10 mL of methanol and $5 \mathrm{~mL}$ of water, sequentially) octadecylsilane reversed-phase cartridge (Baker). The eicosanoids were eluted with $3 \mathrm{~mL}$ of methanol, diluted with $3 \mathrm{~mL}$ of water and subjected to reversed-phase HPLC analysis. The isocratic elution conditions of LTB 4 were THF/methanol/water/acetic acid (25$30-45-0.1$, adjusted to $\mathrm{pH} 5.5$ with concentrated $\mathrm{NH}_{3}$, flow rate $0.9 \mathrm{~mL} / \mathrm{min}, 280 \mathrm{~nm}$, whereas 5-HETE was monitored at $232 \mathrm{~nm}$ using methanol/water/acetic acid (77-23-0.1), pH 5.5, flow rate $1.0 \mathrm{~mL} / \mathrm{min}$. Data were recorded on a MacLab data acquisition system (WissTech, Germany), and analysis was performed with the software Peaks on an Apple Macintosh Quadra 700 computer. Integrated areas of the peaks were compared to the $\mathrm{PGB}_{2}$ internal standard and to external standards of authentic samples. Molar absorption coefficients of Samuelsson et al. were used for the calculations. ${ }^{68}$ Inhibition was calculated by the comparison of the mean values of the test compound $(n=3)$ with the control $(n=6-8)$ activity: (1-test compound/control) $\times 100$. Inhibition was statistically significant compared to that of the control (student's $t$ test; $p<0.05$ ). Each $\mathrm{IC}_{50}$ value was derived by interpolation of a $\log$ inhibitor concentration versus response plot using four or more concentrations of the compound, spanning the $50 \%$ inhibition point. Degradation of anthralin, $\mathbf{4 p}$, and $7 \mathbf{j}$ under test conditions: The incubation mixture was diluted with $10 \mathrm{~mL}$ of water and passed through an octadecylsilane reversed- phase cartridge (Baker). After elution with $2 \times 5 \mathrm{~mL}$ of water, the compounds were eluted with $3 \times 1 \mathrm{~mL}$ of methanol and subjected to reversed-phase HPLC analysis. The isocratic elution conditions were methanol/water/acetic acid (85-15-0.1), $254 \mathrm{~nm}$. The concentrations of the compounds and the metabolites bianthrone and danthron were determined from comparison of the corresponding peak area with known amounts of standards.

Acknowledgment. We thank Mrs. C. Braun and Mr. K. Ziereis for their excellent technical assistance, Dr. K. K. Mayer for the mass spectral measurement, Mr. G. Wandinger for the elemental analyses, and Prof. Dr. G. Wurm, Berlin, for a gift of lonapalene. D.G. thanks the Schlosser-Stiftung for a scholarship.

\section{References}

(1) Christophers, E. R.; Krueger, G. C. Psoriasis. In Dermatology in General Medicine; Fitzpatrick, T. B., Eisen, A., Wolff, K., Freedberg, I. M., Austen, K. F., Eds.; McGraw-Hill: New York, 1987; pp 461-491.

(2) Fry, L. Psoriasis. Br. J. Dermatol. 1988, 119, 445-461.

(3) Brain, S. D.; Camp, R. D. R.; Cunningham, F. M.; Dowd, P. M.; Greaves, M. W.; Kobza Black, A. Leukotriene B4-like material in scale of psoriatic skin lesions. Br. J. Pharmacol. 1984, 83, 313-317.

(4) Grabbe, J.; Czarnetzki, B. M.; Rosenbach, T.; Mardin, M. Identification of chemotactic lipoxygenase products of arachidonate metabolism in psoriatic skin. J. Invest. Dermatol. 1984, 82, 477479.

(5) Duell, E. A.; Ellis, C. N.; Voorhees, J. J. Determination of 5,12, and 15-lipoxygenase products in keratomed biopsies of normal and psoriatic skin. J. Invest. Dermatol. 1988, 91, 446-450.

(6) Fogh, K.; Herlin, T.; Kragballe, K. Eicosanoids in acute and chronic psoriatic lesions: Leukotriene $B_{4}$, but not 12-hydrory-eicosatetraenoic acid, is present in biologically active amounts in acute guttate lesions. J. Invest. Dermatol. 1989, 92, 837-841.

(7) Ford-Hutchinson, A. W. Potential and therapeutical value of development of novel 5-liporygenase inhibitors. In Lipoxygenases and Their Products; Cooke, S. T., Wong, A., Eds.; Academic Press: London, 1991; pp 137-160.

(8) Jones, G. H.; Venuti, M. C.; Young, J. M.; Krishna Murthy, D. V.; Loe, B. E.; Simpson, R. A.; Berks, A. H.; Spires, D. A.; Maloney, P. J.; Kruseman, M.; Rouhafza, S.; Kappas, K. C.; Beard, C. C.; Unger, S. H.; Cheung, P. S. Topical nonsteroidal antipsoriatic agents: 1.1,2,3,4-Tetraorygenated naphthalene derivatives.J.Med. Chem. 1986, 29, 1504-1511.

(9) Venuti, M. C.; Loe, B. E.; Jones, G. H.; Young, J. M. Topical nonsteroidal antipsoriatic drugs. 2. 2,3-(Alkylidenedioxy)naphthalene analogues of lonapalene. J. Med. Chem. 1988, 31, 21322136.

(10) Batt, D. G.; Maynard, G. D.; Petraitis, J. J.; Shaw, J. E.; Galbraith, W.; Harris, R. R. 2-Substituted-1-naphthols as potent 5-lipoxygenase inhibitors with topical antiinflammatory activity. J. Med. Chem. 1990, 33, 360-370.

(11) Bernd, A.; Holzmann, H.; Marsch, W. C.; Kurelec, B.; Britivic, S. Müller, W. E. G. Antimutagenic potency of the cytotoxic and antipsoriatic compound anthralin (cignolin). Pharmacol. Res. Commun. 1987, 19, 367-378.

(12) Mustakallio, K. K. Anthralin and related compounds. Past, present and future. In Psoriasis, Proceedings of the Fourth International Symposium; Farber, E. M., Nall, L., Morhenn, V., Jacobs, P. H., Eds.; Elsevier: New York, 1988; pp 172-180.

(13) Shroot, B.; Brown, C. Free radicals in skin exposed to dithranol and its derivatives. Arzneim.-Forsch. 1986, 36, 1253-1255.

(14) Müller, K.; Wiegrebe, W.; Younes, M. Formation of active oxygen species by dithranol, III. Dithranol, active orygen species and lipid peroxidation in vivo. Arch. Pharm. (Weinheim, Ger.) 1987, 320, $59-66$.

(15) Müller, K.; Kappus, H. Hydroxyl radical formation by dithranol. Biochem. Pharmacol. 1988, 37, 4277-4280.

(16) Fuchs, J.; Packer, L. Investigations on anthralin free radicals in model systems and in skin of hairless mice. J. Invest. Dermatol. $1989,92,677-682$.

(17) Lambelet, P.; Ducret, F.; Löliger, J.; Maignan, J.; Reichert, U.; Shroot, B. The relevance of secondary radicals in the mode of action of anthralin. Free Radical Biol. Med. 1990, 9, 183-190.

(18) Müller, K.; Kanner, R. C.; Foote, C. S. Kinetic studies on anthralin photooxidation. Photochem. Photobiol. 1990, 52, 445-450.

(19) Müller, K.; Gürster, D. Hydroxyl radical damage to DNA sugar and model membranes induced by anthralin (dithranol). Biochem. Pharmacol. 1993, 46, in press.

(20) Fuchs, J.; Nitschmann, W.; Packer, L. Antioxidant and prooxidant effects of the antipsoriatic compound anthralin in skin and subcellular fractions. In Antioxidants in Therapy and Preventive Medicine; Emerit, I., Packer, L., Auclair, C., Eds.; Plenum Press: New York, 1990; pp 537-541. 
(21) Bedord, C. J.; Young, J. M.; Wagner, B. M. Anthralin inhibition of mouse epidermal arachidonic acid lipoxygenase in vitro. J. Invest. Dermatol. 1983, 81, 566-571.

(22) Schröder, J.-M. Anthralin (1,8-dihydroxyanthrone) is a potent inhibitor of leukotriene production and LTB 4 - $\omega$ oxidation by human neutrophils. J. Invest. Dermatol. 1986, 87, 624-629.

(23) Musser, J. H.; Kreft, A. F. 5-Lipoxygenase: properties, pharmacology, and the quinolinyl(bridged)aryl class of inhibitors. J. Med. Chem. 1992, 35, 2501-2524.

(24) Ikuta, H.; Shirota, H.; Kobayashi, S.; Yamagishi, Y.; Yamada, K.; Yamatsu, I.; Katayama, K. Synthesis and antiinflammatory activities of 3-(3,5-di-tert-butyl-4-hydroxybenzylidene)pyrrolidin-2ones. J. Med. Chem. 1987, 30, 1995-1998.

(25) Hammond, M. L.; Kopka, I. E.; Zambias, R. A.; Caldwell, C. G.; Boger, J.; Baker, F.; Bach, T.; Luell, S.; MacIntyre, D. E. 2,3-Dihydro-5-benzofuranols as antioxidant-based inhibitors of leukotriene biosynthesis. J. Med. Chem. 1989, 32, 1006-1020.

(26) Hammond, M. L.; Zambias, R. A.; Chang, M. N.; Jensen, N. P.; McDonald, J.; Thompson, K.; Boulton, D. A.; Kopka, I. E.; Hand, K. M.; Opas, E. E.; Luell, S.; Bach, T.; Davies, P.; MacIntyre, D. E.; Bonney, R. J.; Humes, J. L. Antioxidant-based inhibitors of leukotriene biosynthesis. The discovery of $6-[1-[2-(h y d r o x y m e t h y l)-$ phenyl]-1-propen-3-yl]-2,3-dihydro-5-benzofuranol, a potent topical antiinflammatory agent. J. Med. Chem. 1990, 33, 908-918.

(27) Lazer, E. S.; Wong, H.-C.; Possanza, G. J.; Graham, A. G.; Farina, P.R. Antiinflammatory 2,6-di-tert-butyl-4-(2-arylethenyl)phenols. J. Med. Chem. 1989, 32, 100-104.

(28) Lazer, E. S.; Wong, H.-C.; Wegner, C. D.; Graham, A. G.; Farina, P. R. Effect of structure on potency and selectivity in 2,6disubstituted 4-(2-arylethenyl)phenol lipoxygenase inhibitors. $J$. Med. Chem. 1990, 33, 1892-1898.

(29) Ohkawa, S.; Terao, S.; Terashita, Z.; Shibouta, Y.; Nishikawa, K. Dual inhibitors of thromborane $A_{2}$ synthase and 5-liporygenase with scavenging activity of active orygen species. Synthesis of a novel series of (3-pyridylmethyl) benzoquinone derivatives. J. Med. Chem. 1991, 34, 267-276.

(30) Yu, M. J.; McGowan, J. R.; Phebus, L. A.; Towner, R. D.; Ho, P K.; Keith, P. T.; Luttman, C. A.; Saunders, R. D.; Ruterbories, K. J.; Lindstrom, T. D.; Wikel, J. H.; Morgan, E.; Hahn, R. A Benzylamine antioxidants: relationship between structure, peroxyl radical scavenging, lipid peroxidation inhibition, and cytoprotection. J. Med. Chem. 1993, 36, 1262-1271.

(31) Hellier, F. F. Whitefield, M. The treatment of psoriasis with triacetoxyanthracene. Br. J. Dermatol. 1967, 79, 491-496.

(32) Kammerau, B.; Zesch, A.; Schaefer, H. Absolute concentrations of dithranol and triacetyl-dithranol in the skin layers after local treatment: in vivo investigations with four different types of pharmaceutical vehicles. J. Invest. Dermatol. 1975, 64, 145-149.

(33) Greaves, M. W. Irritation and staining by 10-butyryl-dithranol (butantrone). Int. J. Clin. Pharmacol. Res. 1986, 6, 315-316.

(34) Van Duuren, B. L.; Segal, A.; Tseng, S. S.; Rusch, G. M.; Loewengart, G.; Maté, U.; Roth, D.; Melchionne, S.; Seidman, I. Structure and tumor-promoting activity of analogues of anthralin (1,8-dihydroxy9-anthrone). J. Med. Chem. 1978, 21, 26-31.

(35) Kratzl, K.; Billek, G. The chemistry of vanillin and its derivatives IV. Synthesis of d,l-coclaurins. Monatsh. Chem. 1952, 83, 10451054.

(36) Clark, C. R.; Davenport, T. W. Anticonvulsant activity of some 4-aminophenylacetamides. J. Pharm. Sci. 1987, 76, 18-20.

(37) Walstra, P.; Verhagen, J.; Veldink, G. A.; Vliegenthart, J. F. G. Leukotriene formation by bovine polymorphonuclear leukocytes. Biochim. Biophys. Acta 1984, 795, 499-503.

(38) Dannhardt, G.; Lehr, M. In-vitro evaluation of 5-liporygenase and cyclo-orygenase inhibitors using bovine neutrophils and platelets and HPLC. J. Pharm. Pharmacol. 1992, 44, 419-424.

(39) Tanzer, H.; Braun, C.; Seidel, M.; Wiegrebe, W. Anthralin derivatives - inhibition of 5-lipoxygenase - antipsoriatic efficacy. Arch. Pharm. (Weinheim, Ger.) 1991, 324, 841-846.

(40) Wiegrebe, W.; Gerber, A.; Kappler, J.; Bayerl, C. Studies on the metabolism of antipsoriatic anthrone-derivatives. Arzneim.-Forsch. 1979, 29, 1083-1088.

(41) Schaltegger, A.; Brunner, F.; Steiger, W.; Krebs, A. Dithranol: further investigations on the structure-activity-relationship. The new series of the 10-mono-alkyldithranol derivatives. Dermatologica $1987,175,136-141$.

(42) Tateson, J. E.; Randall, R. W.; Reynolds, C. H.; Jackson, W. P.; Bhatacherjee, P.; Salmon, J. A.; Garland, L. G. Selective inhibition of arachidonate 5-liporygenase by novel acetohydroxamic acids: biochemical assessment in vitro and ex vivo. Br. J. Pharmacol. 1988, 94, 528-539.

(43) Hatzelmann , A.Fruchtmann, R.;Mohrs, K. H.;Raddatz, S.; MüllerPeddinghaus, R. Mode of action of the new selective leukotriene synthesis inhibitors Bay X 1005 \{(R)-2-[4-(quinolin-2-yl-methoxy)phenyl]-2-cyclopentyl acetic acid\} and structurally related com- pounds. Biochem. Pharmacol. 1993, 45, 101-111.

(44) Summers, J. B.; Kim, K. H.; Mazdiyasni, H.;Holms, J. H.; Ratajczyk J. D.; Stewart, A. O.; Dyer, R. D.; Carter, G. W. Hydrozamic acid inhibitors of 5-liporygenase: quantitative structure-activity relationships. J. Med. Chem. 1990, 33, 992-998.

(45) Unger, S. H.; Cook, J. R.; Hollenberg, J. S. Simple procedure for determining octanol-aqueous partition, distribution, and ionization coefficients by reversed-phase high-pressure liquid chromatography. J. Pharm. Sci. 1978, 67, 1364-1367.

(46) Blois, M. S. Antioxidant determinations by the use of a stable free radical. Nature 1958, 181, 1199-1200.

(47) Kato, K.; Terao, S.; Shimamoto, N.; Hirata, M. Studies on scavengers of active orygen species. 1 . Synthesis and biological activity of 2-Oalkylascorbic acids. J. Med. Chem. 1988, 31, 793-798.

(48) Halliwell, B.; Grootveld, M.; Gutteridge, J. M. C. Methods for the measurement of hydroxyl radicals in biochemical systems: deoxyribose degradation and aromatic hydroxylation. Methods Biochem. Anal. 1988, 33, 59-90.

(49) Gutteridge, J. M. C. Reactivity of hydroxyl and hydroxyl-like radicals discriminated by release of thiobarbituric acid-reactive material from deory sugars, nucleosides and benzoate. Biochem. J. 1984, 224, 761-767.

(50) Laughton, M. J.; Halliwell, B.; Evans, P. J.; Hoult, J. R. S. Antioxidant and prooxidant actions of the plant phenolics quercetin gossypol and myricetin. Effects on lipid peroxidation, hydroxyl radical generation and bleomycin-dependent damage to DNA. Biochem. Pharmacol. 1989, 38, 2859-2865.

(51) Gutteridge, J. M. C. The measurement of malondialdehyde in peroxidized ox-brain phospholipid liposomes. Anal. Biochem. 1977, $82,76-82$.

(52) Aruoma, O. I.; Laughton, M. J.; Halliwell, B. Carnosine, homocarnosine and anserine: could they act as antioxidant in vivo? Biochem. J. 1989, 264, 863-869.

(53) Thody, V.E.; Buckle, D. R.; Foster, K. A. Studies on the antioridant activity of 5-lipoxygenase inhibitors. Biochem. Soc. Trans. 1987, $15,416-417$.

(54) Laughton, M. J.; Evans, P. J.; Moroney, M. A.; Hoult, J. R. S.; Halliwell, B. Inhibition of mammalian 5-liporygenase by flavonoids and phenolic dietary additives. Biochem. Pharmacol. 1991,42, 16731681.

(55) Percival, M. D. Human 5-lipoxygenase contains an essential iron. J. Biol. Chem. 1991, 266, 10058-10061.

(56) Nelson, M. J.;Batt, D. G.; Thompson, J.S.; Wright, S. W. Reduction of the active-site iron by potent inhibitors of lipoxygenases. J. Biol. Chem. 1991, 266, 8225-8229.

(57) Bruneau, P.; Delvare, C.; Edwards, M. P.; McMillan, R. M. Indazolinones, a new series of redor-active 5-liporygenase inhibitors with built-in selectivity and oral activity. J. Med. Chem. 1991, 34, 1028-1036.

(58) Rouzer, C. A.; Riendeau, D.; Falgueyret, J.-P.; Lau, C. K.; Gresser, M. J. Inhibition of human leukocyte 5-lipoxygenase by a 4-hydroxybenzofuran, L-656,224. Evidence for enzyme reduction and inhibitor degradation. Biochem. Pharmacol. 1991, 41, 1365-1373.

(59) Riendeau, D.; Falgueyret, J.-P.; Guay, J.; Ueda, N.; Yamamoto, S. Pseudoperoxidase activity of 5-liporygenase stimulated by potent benzofuranol and $\mathrm{N}$-hydroxyurea inhibitors of the liporygenase reaction. Biochem. J. 1991, 274, 287-292.

(60) Carlsson, A.; Lindqvist, M.; Fila-Hromadko, S.; Corrodi, H. Synthesis of compounds inhibiting catechol- $O$-methyl-tranferase. Compounds acting in catecolamine metabolism. Helv. Chim. Acta $1962,45,270-276$.

(61) Ershov, V. V.;Belostotskaya, I. S. Synthesis of hydroxyphenylacetic acids in the series of sterically hindered phenols. Bull. Acad. Sci. USSR, Div. Chem. Sci. (Engl. Transl.) 1965, 2, 358-360.

(62) Auterhoff, H.; Scherff, F. C. Dianthrones of pharmaceutically interesting hydroxyanthraquinones. Arch. Pharm. (Weinheim, Ger.) 1960, 293, 918-925.

(63) Kipping, F. S.; Hill, A. $\alpha$-Ketotetrahydronaphthalene. J. Chem. Soc. $1899,75,144-153$.

(64) Klein, J.; Bergmann, E. D. The reaction of acetals with malonic acid and its derivatives. A contribution to the knowledge of the Knoevennagel-Doebner reaction. J. Am. Chem. Soc. 1957, 79, 34523454.

(65) Weidner, R.; Würthwein, E.-U. 2-Azaallenium-salts from N-benzylidene- $\alpha$-methoxybenzylamines. Chem. Ber. 1989, 122, 1095-1106.

(66) Straus, F.; Berkow, A. Reactions of unsaturated halogen compounds. II. Cinnamaldehyde and phenyl vinyl ketone. Liebigs Ann. Chem. 1913, 401, 121-159.

(67) Gutteridge, J. M. C. The use of standards for malondialdehyde. Anal. Biochem. 1975, 69, 518-526.

(68) Borgeat, P.; Samuelsson, B. Arachidonic acid metabolism in polymorphonuclear leukocytes: effects of ionophore A23187. Proc. Natl. Acad. Sci. U.S.A. 1979, 76, 2148-2152. 